\title{
Intravenous Irons: From Basic Science to Clinical Practice
}

\author{
Sunil Bhandari ${ }^{1}$ (1D), Dora I. A. Pereira ${ }^{2,3}$, Helen F. Chappell ${ }^{4}$ and Hal Drakesmith ${ }^{5,6, *}$ \\ 1 Hull and East Yorkshire Hospitals NHS Trust and Hull York Medical School, Hull HU3 2JZ, UK; \\ Sunil.Bhandari@hey.nhs.uk \\ 2 Department of Pathology, University of Cambridge, Cambridge CB2 1QP, UK; diap2@cam.ac.uk \\ 3 MRC Unit The Gambia at the London School of Hygiene \& Tropical Medicine, Banjul, Gambia \\ 4 School of Food Science and Nutrition, University of Leeds, Leeds LS2 9JT, UK; H.F.Chappell@leeds.ac.uk \\ 5 MRC Human Immunology Unit, Weatherall Institute of Molecular Medicine, University of Oxford, \\ Headington, Oxford OX3 9DS, UK \\ 6 Haematology Theme Oxford Biomedical Research Centre, Oxford OX3 9DS, UK \\ * Correspondence: alexander.drakesmith@ndm.ox.ac.uk; Tel.: +44-1865-222699
}

Received: 1 August 2018; Accepted: 23 August 2018; Published: 27 August 2018

\begin{abstract}
Iron is an essential trace mineral necessary for life, and iron deficiency anaemia (IDA) is one of the most common haematological problems worldwide, affecting a sixth of the global population. Principally linked to poverty, malnutrition and infection in developing countries, in Western countries the pathophysiology of IDA is primarily linked to blood loss, malabsorption and chronic disease. Oral iron replacement therapy is a simple, inexpensive treatment, but is limited by gastrointestinal side effects that are not inconsequential to some patients and are of minimal efficacy in others. Third generation intravenous (IV) iron therapies allow rapid and complete replacement dosing without the toxicity issues inherent with older iron preparations. Their characteristic, strongly-bound iron-carbohydrate complexes exist as colloidal suspensions of iron oxide nanoparticles with a polynuclear Fe(III)-oxyhydroxide/oxide core surrounded by a carbohydrate ligand. The physicochemical differences between the IV irons include mineral composition, crystalline structure, conformation, size and molecular weight, but the most important difference is the carbohydrate ligand, which influences complex stability, iron release and immunogenicity, and which is a unique feature of each drug. Recent studies have highlighted different adverse event profiles associated with third-generation IV irons that reflect their different structures. The increasing clinical evidence base has allayed safety concerns linked to older IV irons and widened their clinical use. This review considers the properties of the different IV irons, and how differences might impact current and future clinical practice.
\end{abstract}

Keywords: adverse event profile; anaemia; bioengineering; labile iron; intravenous iron; iron-carbohydrate complex; iron processing

\section{Introduction}

Iron, the most abundant element on earth, accounting for 35\% of the earth's mass, is an essential trace mineral necessary for a myriad of metabolic reactions in the body. These include a role in catalytic enzymes and proteins for DNA synthesis, transport of oxygen in haemoglobin and myoglobin, mitochondrial cell respiration, oxidative phosphorylation and adenosine triphosphate (ATP) formation in the tricarboxylic acid cycle [1-3]. The human body contains $3-5 \mathrm{~g}$ iron and is essential for life, but iron acquisition and assimilation in humans is challenging as oxidised iron is poorly soluble at neutral $\mathrm{pH}$, and within the body, "free" iron is toxic through the promotion of reactive oxygen 
species. Thus, multiple, complex systems have evolved in man to manage and retain iron, yet iron deficiency and iron deficiency anaemia (IDA) are common problems [4]. Oral iron therapy is a simple, inexpensive treatment, but is limited by gastrointestinal side effects that are not inconsequential to some patients and are of minimal efficacy in others [5]. Advances in our understanding of the pathophysiology of iron metabolism and the development of new pharmaceutical technologies have led to a better understanding of the need for and development of intravenous (IV) formulations for iron replacement when oral iron preparations are not efficacious or cannot be used. This review considers the properties of the different IV irons, and how differences might impact current and future clinical practice.

\section{Iron Deficiency Anaemia}

Iron deficiency is the most common nutritional deficiency worldwide. IDA is one of the most common haematological problems, and the most important cause of a microcytic, hypochromic anaemia. Globally, 1.24 billion people are affected by IDA, which corresponds to about a sixth of the global population [4]. The Global Burden of Disease project highlighted the significant public health importance of IDA, with around 35,000,000 disability-adjusted life years globally attributable to IDA, ranking it fourth in the top leading causes of disability [4]. It is associated with multiple disease states, including chronic kidney disease (CKD), inflammatory bowel disease (IBD) and congestive heart failure and contributes to loss of wellbeing and poor outcomes for patients [6,7]. From a health system perspective, identification and correction of perioperative IDA reduces rates of transfusion and mortality rates, as well as length of hospital stay [8,9]. Regardless of whether IDA is symptomatic, all patients should be treated-both by addressing the underlying cause of the iron deficiency and through adequate replenishment of iron stores. More recently, emerging data also suggest benefit in the treatment of non-anaemic iron deficiency (NAID) with replacement iron [10,11].

\subsection{Pathophysiology of IDA}

Principally linked to poverty, malnutrition and infection in developing countries, in western countries the pathophysiology of IDA is primarily linked to blood loss, malabsorption and chronic disease (Table 1) [7]. Chronic blood loss occurs in a range of conditions that include peptic ulcer disease, inflammatory bowel diseases, regular haemodialysis therapy, occult intestinal cancer and heavy menstrual bleeding. Impaired iron absorption is often apparent after gastrectomy and in inflammatory bowel diseases, and chronic diseases such as CKD are characterised by impaired erythropoiesis through iron restriction. Loss of iron in the urine can occur through rare forms of intravascular haemolysis, and IDA can be drug-related (proton-pump inhibitors, leading to impaired absorption due to increased gastric $\mathrm{pH}$ ) and genetic (iron-refractory iron-deficiency anaemia, IRIDA) [7].

Table 1. Main causes of iron deficiency in the western world [7].

\begin{tabular}{l|l}
\hline \multicolumn{1}{c}{ Cause } & \multicolumn{1}{c}{ Details } \\
\hline Insufficient uptake & Malnutrition or diet-related (low-iron, vegetarian, vegan) \\
\hline $\begin{array}{l}\text { Increased physiological } \\
\text { demand }\end{array}$ & $\begin{array}{l}\text { Rapid growth during infancy/adolescence, menstrual blood loss, pregnancy } \\
\text { (2nd/3rd trimesters) }\end{array}$ \\
\hline Chronic blood loss & Trauma, surgery, delivery, heavy menstrual bleeding \\
\hline Chronic disease & $\begin{array}{l}\text { Kidney disease, heart failure, inflammatory bowel disease, gastritis, peptic ulcer, } \\
\text { intestinal cancer and benign tumours }\end{array}$ \\
\hline Drug-related & $\begin{array}{l}\text { Glucocorticoids, salicylates, non-steroidal anti-inflammatory drugs, proton-pump } \\
\text { inhibitors, } \mathrm{H}_{2} \text {-receptor antagonists, drug-induced haemolytic anaemia }\end{array}$ \\
\hline Genetic & Iron-refractory iron-deficiency anaemia, thalassaemia and sickle cell anaemia \\
\hline
\end{tabular}

IRIDA is caused by mutations/polymorphisms in the gene TMPRSS6 (transmembrane protease, serine 6) [12]. This anaemia offers useful insights into the normal iron-control mechanisms in 
humans. The consequence of TMPRSS6 loss of function mutations is constitutively high levels of the iron-regulatory hormone hepcidin, a 25-amino acid peptide that together with the sole iron exporter in the body, ferroportin, control iron homeostasis (Figure 1). High levels of hepcidin result in ferroportin loss from cell membranes and cessation of iron export to plasma. This explains the inability to absorb intestinal iron in IRIDA cases and thus the muted response to treatment with oral iron preparations [13]. This can be partly overcome if sufficiently high quantities of oral iron are administered as demonstrated in studies of the phosphate binder ferric citrate [14].

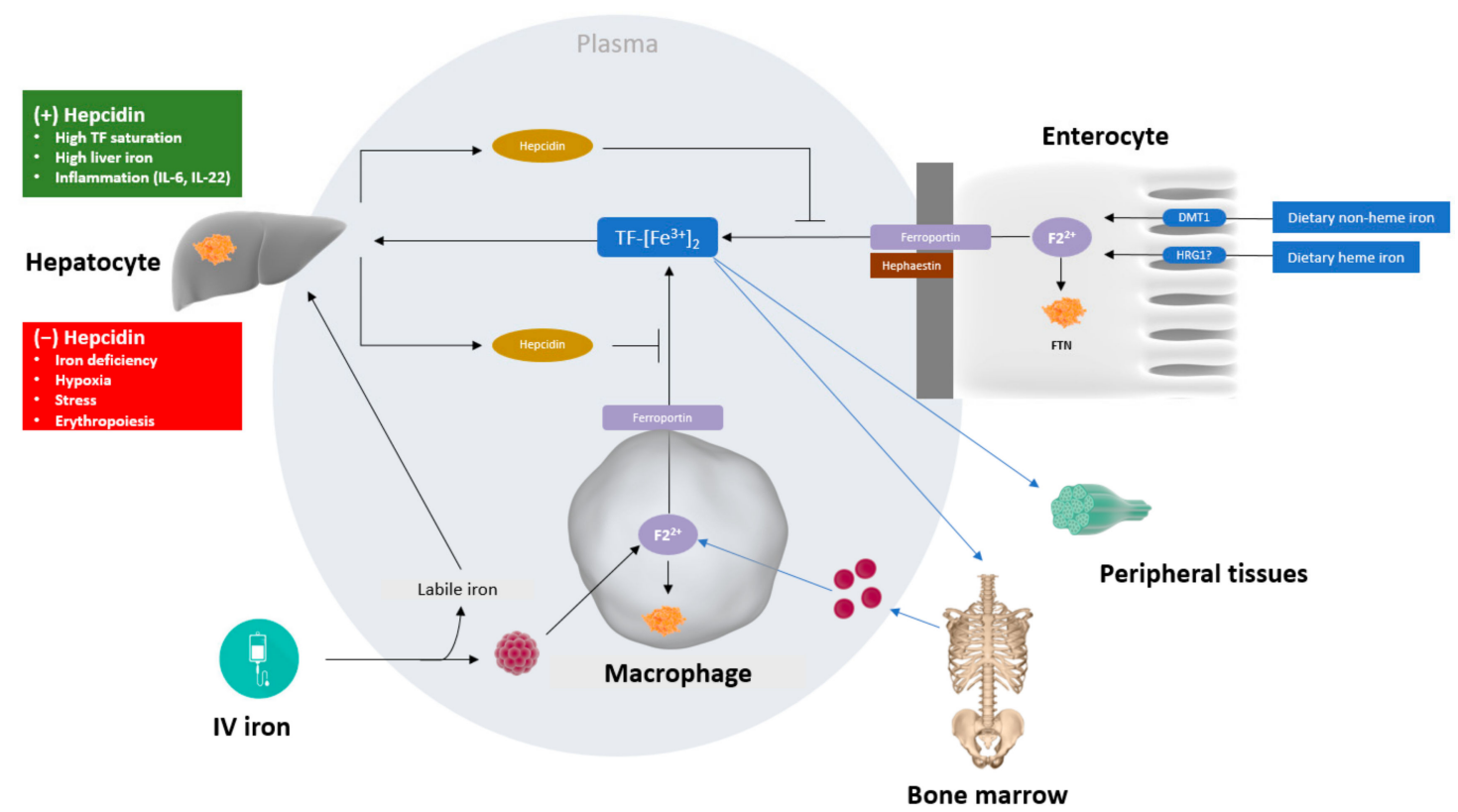

Figure 1. A simplified overview of iron metabolism. The major flow of iron in the body is via transferrin (TF), which transports iron from iron absorption in the enterocytes in the duodenum, the recycling of iron from senescent erythrocytes within macrophages of the reticuloendothelial system, and the mobilisation of iron storage within ferritin (FTN), that mainly resides within macrophages and hepatocytes. Iron export to plasma is mediated via the sole iron exporter, ferroportin and is controlled by its ligand, hepcidin, which is secreted into blood plasma mainly by hepatocytes. Hepcidin binds to ferroportin and controls ferroportin concentration through promoting its endocytosis. Almost all plasma iron is bound to TF, but after infusion of iron supplements, labile (unbound) iron may appear in plasma. The molecular structure of third generation IV irons confers stability on the iron complex, with the intention of limiting the amount of labile iron entering the plasma after infusion and ensuring a controlled release of iron from the complex once taken up by macrophages. How the different IV iron complexes are handled in the macrophage and the basis for their different solubility is not well characterised, but will be dependent not only on $\mathrm{pH}$, but the low molecular weight molecules that are present in the lysosome and their different iron-binding affinities and on macrophage polarisation/differentiation. Iron released from the iron-carbohydrate complex is either stored as ferritin or transported out of the macrophage and bound to TF.

Hepcidin and iron regulatory proteins (IRPs) are essential for maintaining iron homeostasis [15]. Hepcidin production from the liver is increased in the presence of inflammation, in particular in the presence of the inflammatory cytokine interleukin-6 and is an underlying mechanism of IDA associated with chronic disease [16]. Chronic inflammation, for example related to CKD, increases hepcidin production, in turn inhibiting both the uptake of dietary iron and the mobilization of stored iron from the reticuloendothelial system to circulating transferrin [17]. This restricts the availability of iron for erythropoiesis, which is often superimposed on underlying true iron deficiency and may, 
therefore, be termed functional iron deficiency as there are sufficient iron stores but an inability to access them due to elevated hepcidin $[18,19]$.

\subsection{Iron Supplementation Strategies}

Historically, oral iron replacement therapy to treat IDA in the form of iron salts dates to the 17th century. Oral ferrous salts are the most commonly prescribed iron replacement therapy, reflecting their efficacy and simplicity of dosing [6,7]. However, long-term treatment of up to 6 months is usually required to adequately replete iron stores, and gastrointestinal side-effects that include nausea and pain are common. A meta-analysis of 43 randomised, controlled trials of 6831 patients reported gastrointestinal side-effects in up to $75 \%$ of patients [5]. These side effects can be underestimated regarding their impact on patients and adherence can be challenging [20].

For those who do not respond to oral iron, understanding the hepcidin-ferroportin axis has provided mechanistic insights into relative "iron resistance". This points to a potential role for hepcidin measurement in clinical practice, with a view to identifying patients most likely or least likely to respond to oral iron therapy. Also, recent studies of NAID have shown that alternate-day dosing of oral iron might optimise iron absorption, as the hepcidin levels fall in the alternate days without iron consumption [10,11].

There is ongoing research interest in the development of original oral irons; in particular, the utilisation of nanotechnology to create novel oral iron nanoformulations [21-25]. One of the strategies proposed is to use the iron core of ferritin, the primary iron-storage protein in cells, as a model. Ferritin has evolved to serve as a highly efficient iron storage protein that is conserved across eukaryotes. Ferritin is composed of an iron oxide nanocore contained within a globular heteropolymeric protein, from which iron release is restricted and controlled [26]. Recently, a nanoparticulate mimetic of the ferritin core was proposed as a potentially side effect-free form of supplemental iron [27] and a paediatric trial is ongoing (NCT02941081). Other trials are on-going with many different oral iron formulations developed to improve absorption and/or tolerability $[14,23,28-30]$.

The first parenteral iron preparations to be used clinically in the early 20th century were colloidal ferric hydroxide preparations, but toxicity linked to the release of large amounts of labile ("free") iron limited their use. This prompted the development of preparations composed of an iron core and carbohydrate shell that prevented rapid release of the elemental iron [13,31]. The introduction of IV iron saccharide in 1947 and high-molecular-weight dextran (HMWD) iron in 1954 signalled a major change in perception of IV iron supplementation due to their efficacy and relative safety. Nonetheless, cases of severe hypersensitivity reactions, in particular the well-documented dextran-induced anaphylactic reactions, led to extreme caution within the medical community regarding the use of these IV irons [13,31].

In the 1990s, two new formulations-iron gluconate and iron sucrose-were developed that used non-dextran carbohydrates complexed with the iron core and these were associated with markedly fewer severe adverse events (SAE). It was shown that patients previously sensitive to HMWD were unlikely to be sensitised to these newer irons [13,31,32]. Development of new pharmaceutical technologies allowed the development of third generation IV irons in an attempt to circumvent the toxicity issues inherent with earlier preparations and the posology limitations of iron sucrose products. In the last ten years, three third-generation IV iron compounds were licensed for the treatment of IDA $[13,31]$. Two are currently approved for use in Europe-ferric carboxymaltose and iron isomaltoside 1000—and one in the United States—ferumoxytol [33].

\section{Bioengineering and Metabolism of IV Iron}

IV iron preparations are bioengineered as iron-carbohydrate complexes to deliver high doses of iron in a stable, non-toxic form [34] and consist of colloidal suspensions of iron oxide nanoparticles with a polynuclear Fe(III)-oxyhydroxide/oxide core surrounded by a carbohydrate ligand [13,31,35-39] (Table 2). In essence, IV irons behave as prodrugs, retaining ionic iron until the iron-carbohydrate 
complex is metabolised [35,36]. The physicochemical differences between the IV irons include mineral composition, crystalline structure, conformation, size and molecular weight, but the key point of difference between IV iron products is the carbohydrate ligand, which influences complex stability, iron release and immunogenicity, and is a unique feature of each drug [13,31,34-38] (Table 3). Schematic models of a high molecular weight iron-carbohydrate complex (iron carboxymaltose) and a low molecular weight complex (iron gluconate) are compared in Figure 2, which illustrates that these are two different particles both in terms of overall size but also, and importantly, in terms of number of iron atoms and how accessible these are to undergo chemical reactions. Iron carboxymaltose contains around 110,000 iron atoms bound to 180,000 oxygen atoms in a dense structure with an approximate core diameter of $18 \mathrm{~nm}$. This makes it more difficult to break down once inside the cells, since the iron atoms are less accessible to chelators or redox reactions, whereas iron gluconate is smaller with a $6 \mathrm{~nm}$ diameter, is less compact and has fewer iron atoms (around 4200 iron atoms bound to 7000 oxygen atoms) and, therefore, the kinetics of iron release from iron gluconate is faster than that of iron release from iron carboxymaltose, meaning that iron gluconate is more labile than iron carboxymaltose.

Table 2. Clinical characteristics of currently available IV irons [13,33,39].

\begin{tabular}{ccccccc}
\hline & Ferumoxytol & $\begin{array}{c}\text { Iron } \\
\text { Carboxymaltose }\end{array}$ & $\begin{array}{c}\text { Iron } \\
\text { Isomaltoside } \\
\mathbf{1 0 0 0}\end{array}$ & $\begin{array}{c}\text { Low Molecular } \\
\text { Weight Iron } \\
\text { Dextran }\end{array}$ & $\begin{array}{c}\text { Iron } \\
\text { Sucrose }\end{array}$ & $\begin{array}{c}\text { Iron } \\
\text { Gluconate }\end{array}$ \\
\hline Brand name & Feraheme $^{\circledR}$ & Ferinject ${ }^{\circledR}$ & Monofer $^{\circledR}$ & Cosmofer $^{\circledR}$ & Venofer $^{\circledR}$ & Ferlixit $^{\circledR}$ \\
\hline $\begin{array}{c}\text { Maximum single } \\
\text { dose }\end{array}$ & $510 \mathrm{mg}$ & $1000 \mathrm{mg}$ & $20 \mathrm{mg} / \mathrm{kg}$ & $20 \mathrm{mg} / \mathrm{kg}$ & $200 \mathrm{mg}$ & $125 \mathrm{mg}$ \\
\hline $\begin{array}{c}\text { Minimum } \\
\text { administration time } \\
\text { (minutes) }\end{array}$ & 15 & 15 & 15 & 60 & 30 & $30-60$ \\
\hline $\begin{array}{c}\text { Replacement dose } \\
\text { possible in a single } \\
\text { infusion }\end{array}$ & No & Yes & Yes & Yes & No & No \\
\hline
\end{tabular}

Table 3. Comparison of physicochemical characteristics and pharmacokinetics of IV irons [37-39].

\begin{tabular}{ccccccc}
\hline & Ferumoxytol & $\begin{array}{c}\text { Iron } \\
\text { Carboxymaltose }\end{array}$ & $\begin{array}{c}\text { Iron } \\
\text { Isomaltoside } \\
\mathbf{1 0 0 0}\end{array}$ & $\begin{array}{c}\text { Low Molecular } \\
\text { Weight Iron } \\
\text { Dextran }\end{array}$ & $\begin{array}{c}\text { Iron } \\
\text { Sucrose }\end{array}$ & $\begin{array}{c}\text { Iron } \\
\text { Gluconate }\end{array}$ \\
\hline $\begin{array}{c}\text { Molecular weight } \\
\text { (Da) }\end{array}$ & 185,000 & 150,000 & 150,000 & 103,000 & 43,000 & 37,500 \\
\hline $\begin{array}{c}\text { Carbohydrate } \\
\text { ligand }\end{array}$ & $\begin{array}{c}\text { Polyglucose sorbitol } \\
\text { carboxymethylether }\end{array}$ & Carboxymaltose & Isomaltoside & $\begin{array}{c}\text { Dextran } \\
\text { polysaccharide }\end{array}$ & $\begin{array}{c}\text { Sluconate, } \\
\text { loosely } \\
\text { associated } \\
\text { sucrose }\end{array}$ \\
\hline $\begin{array}{c}\text { Relative stability } \\
\text { of iron } \\
\text { carbohydrate } \\
\text { complex }\end{array}$ & High & High & High & High & Medium & Low \\
\hline $\begin{array}{c}\text { Reactivity with } \\
\text { transferrin }\end{array}$ & Low & Low & Low & Low & Medium & High \\
\hline $\begin{array}{c}\text { Relative labile } \\
\text { iron release }\end{array}$ & Low & Low & Low & Medium & High & High \\
\hline $\begin{array}{c}\text { Plasma half-life } \\
\text { (hrs) }\end{array}$ & $\sim 15$ & $7-12$ & 20 & $5-20$ & 6 & $\sim 1$ \\
\hline
\end{tabular}



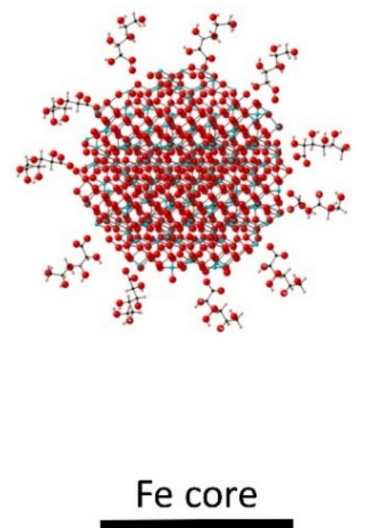

$\sim 6 \mathrm{~nm}$

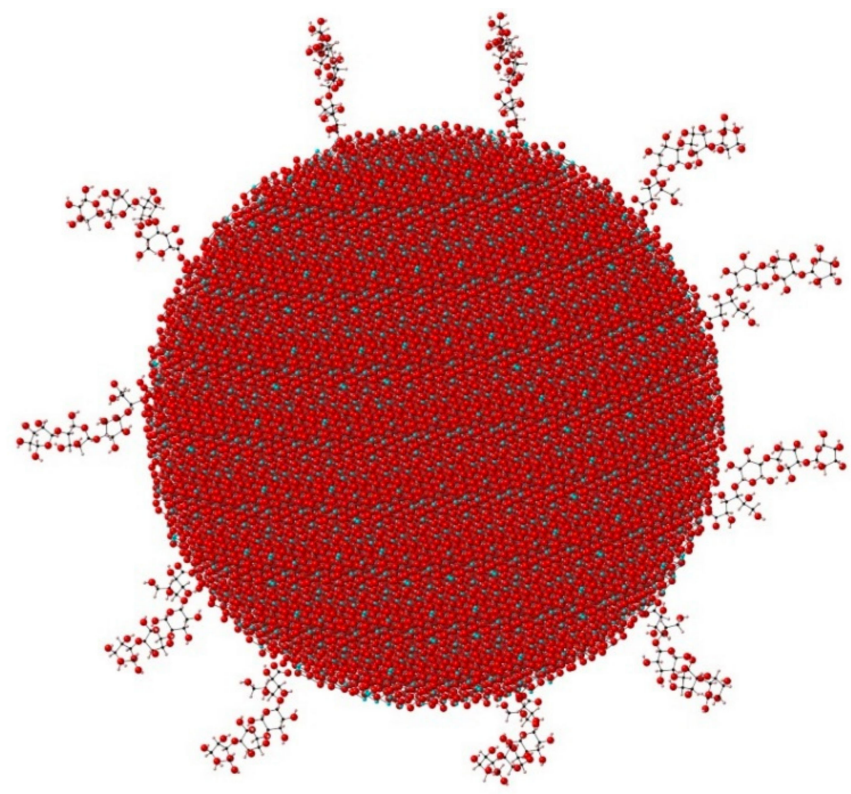

Fe core

$\sim 18 \mathrm{~nm}$

Figure 2. Schematic illustration of the relative size and composition of iron gluconate (left, low molecular weight, 37,500 Da) and iron carboxymaltose (right, high molecular weight, $150,000 \mathrm{Da})$. The models show iron-oxide cores, based on the neutron diffraction-derived structure of ferrihydrite [40], surrounded by the relevant organic ligands. Oxygen is shown in red, hydrogen in pink, carbon in black and iron in blue.

Upon IV infusion, the volume of distribution of IV irons corresponds roughly to the plasma volume. IV irons are processed in macrophages and release functional iron from the carbohydrate ligand $[35,36]$. The iron complex is endocytosed by macrophages within the reticuloendothelial system, mainly in the liver, spleen and bone marrow, but the precise mechanism of recognition and internalization is not fully defined [41]. Endosome-lysosome fusion creates an acidic endolysosome and, combined with endogenous iron-binding due to citric acid and other iron-complexing agents present in the lysosomes, drives iron release from the iron-carbohydrate complex [42]. This may be distinct from the mechanism of iron release from ferritin. Early in-vitro stability analyses suggest that the low $\mathrm{pH}$ of the endolysosome, the type and concentration of low-molecular-weight iron-ligands present in the endolysosome and the stabilities of the different IV iron-carbohydrate structures, are all important for iron liberation [42,43]. However, the precise mechanism of iron liberation is incompletely understood. This is an area of current interest-IV iron metabolism is likely to vary depending on the type and differentiation state of the macrophage processing the iron [44,45], and iron itself can alter macrophage polarisation [46], so that the different characteristics of each iron-carbohydrate complex may potentially affect macrophage function. The latter may well have relevance for the regulatory authorities when defining the extent of similarity between iron-formulations of the same class.

Iron is subsequently transported into the labile iron pool in the macrophage cytoplasm, where it can be stored, or exported into the plasma by ferroportin. The mechanism by which intracellular iron is delivered to ferroportin for export is not well characterised [47]. Upon export, iron is immediately oxidised by ferroxidases, and sequestered by plasma transferrin for transport to erythroid precursor cells for incorporation into haemoglobin or to other iron-requiring cells, or for liver storage in the form of ferritin [35-37] (Figure 1).

The stability of the iron-carbohydrate complex influences the amount of labile iron that is present in the formulation [32,37]. Strongly-bound iron-carbohydrate complexes characterise the 
third-generation IV irons. These stable, robust complexes bind iron tightly and do not release large amounts of labile, non-transferrin-bound iron (NTBI) into the blood before macrophage uptake. As a result, the risk of infusion reactions caused by labile iron is diminished and are clinically well-tolerated even at high doses [13,31,32,35,37,39,48,49]. This allows rapid, high-dose infusion of doses of 1000-1500 mg, thus offering the potential for complete iron replacement in 15-60 min (Table 2), although processing and distribution of the iron will obviously take longer. Comprehensive biochemical quantification of the different IV irons preparations confirms differences in complex stability and labile iron release (Figure 3) [32].

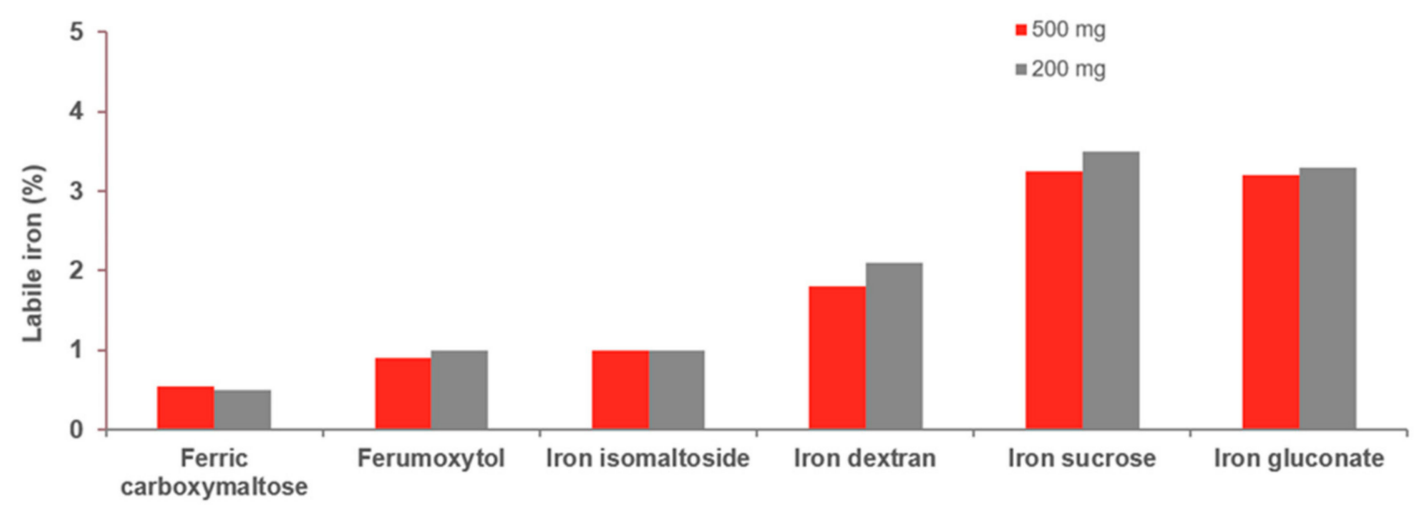

Figure 3. In vivo comparison of labile iron potential of IV iron preparations. Results of the determination of detectable labile iron in human serum as a percentage of total dose given (200 $\mathrm{mg}$ and $500 \mathrm{mg}$ ), using the Ferrozine ${ }^{\circledR}$-method (adapted from Jahn et al., 2011 [32]).

Compared with third-generation irons, the lower molecular weight iron sucrose complexes have lower complex stability, are termed semi-robust, moderately strong, and release larger amounts of NTBI into the blood [37]. As a result, maximal single doses are significantly lower with longer administration times [33,37]. Ferric gluconate preparations contain variable amounts of low-molecular-weight components $(<18,000$ Daltons), are characteristically labile and weak, and generate larger amounts of labile NTBI [37]. Labile iron also has the potential for formation of highly reactive free radicals causing oxidative stress [50]. Under normal physiological conditions, iron in the body exists in a non-redox-active form, i.e., it is not able to repetitively complete coupled reduction and oxidation, as in ferritin and transferrin. However, should iron infusions lead to complete or near-complete saturation of transferrin, the subsequent high levels of labile, redox-active iron, particularly with high-dose infusion, may contribute to formation of reactive oxygen species and reactive nitrogen species in an uncontrolled way. These entities cause oxidative and/or nitrosative stress that upsets normal cellular signalling mechanisms and has been shown to be involved in many diseases, including heart failure, and Alzheimer's disease, Friedreich's ataxia and Parkinson's disease [35,39].

A further consideration is the risk of dextran-related immune reactions and clinical hypersensitivity reactions more generally. Dextran, given intravenously, can result in IgG-mediated anaphylaxis [34]. Early IV formulations of high-molecular-weight iron dextran caused rare but serious allergic reactions that led to anaphylaxis [13,31]. The formulation of iron dextran (lower molecular weight) currently available is associated with markedly lower rates of adverse events [51-54]. For third-generation IV iron preparations, the carbohydrate component of the iron-carbohydrate complex is responsible for immune recognition and eliciting hypersensitivity reactions. It is now thought that a complement activation-related pseudo-allergy is likely a more common pathogenetic mechanism in acute reactions to currently licensed IV iron than a response that is immunological and IgE-mediated [55]. The response is likely triggered by iron nanoparticles and influenced by the unique carbohydrate-iron complex of each IV iron. 
Thus, the structure and physiochemical characteristics of IV irons have implications for therapy, impacting the maximum amount of iron that can be infused, the rate of infusion, the risk of minor infusion reactions, the risk of immune-mediated hypersensitivity reactions, and wider negative effects linked to the toxicity of labile iron.

\section{Regulatory View of IV Iron Formulations and Bioequivalence}

The complexity of the IV iron formulations underlies the ongoing issue regarding approval of generic copies of non-biologic complex drugs. The authorisation process for generic pharmaceuticals is currently based on pharmaceutical equivalence which encompasses demonstration of 'sameness' of the active pharmaceutical ingredient and bioequivalence to the listed reference product without the need for efficacy studies and establishing a safety profile. With the availability of iron sucrose similars in the European Union, differences in clinical efficacy and safety profiles to the originator drug have been reported [56-63].

With this background, the regulators have taken notice of the complexity of IV iron formulations. Both the Food and Drug Administration (FDA) and European Medicines Agency (EMA) acknowledge that IV iron-carbohydrate nanoparticle preparations cannot be authorised by this well-established generic approval paradigm for small molecules. The EMA and FDA have reflected on the data requirements to define similarity and the possibility of interchanging or switching between different IV iron formulations; these include stepwise in vitro, non-clinical and clinical testing as a prerequisite [64-66]. The EMA has concluded that the stability of IV iron-carbohydrate complexes and the physicochemical properties of both the iron and the carbohydrate impact the quality attributes of the different drugs, which have the potential to influence both safety and efficacy [66]. This position draws into question the view that IV irons are substitutable and interchangeable and suggests caution should be exercised when switching between IV irons, with appropriate efficacy and safety monitoring put in place.

\section{Clinical Use of IV Iron}

The prescribing of IV irons across a broad range of indications reflects the breadth of conditions that manifest IDA. IV iron use has dramatically increased, and the broad and increasing number of conditions for which IV iron has been investigated is at least in part supported by their safety profile. An extensive meta-analysis of $>10,000$ patients derived from 103 clinical trials offers important insights into the overall safety profile and allows comparison between IV and oral iron [67]. IV iron was not associated with an increase in serious AEs (SAE) when compared to oral iron and placebo (RR, 1.04; 95\% CI, 0.93-1.14). SAE were rare, estimated to occur in 1:200,000 doses with no fatal or anaphylactic reactions reported [67]. Although the study confirmed that minor infusion reactions do occur, the frequency of these adverse events must be considered in the context of the use of blood transfusions. In many cases, transfusions are the only alternative to IV iron to correct IDA when oral iron is ineffective or not tolerated or in acute situations when there is not enough time for oral iron to replenish iron levels.

A limitation of the meta-analysis is the short-term nature of randomised clinical trials (RCTs), with long-term adverse events not being tracked (67). For conditions such as CKD that are dependent on ongoing long-term dialysis and frequent iron infusions, there are some concerns about the long-term safety outcomes. This concern in part relates to the potential for oxidative stress linked to IV iron use, especially in the context of the ongoing chronic inflammatory processes characteristic of CKD. A large, clinical study (proactive IV iron therapy in haemodialysis patients, PIVOTAL, EudraCT number 2013-002267-25) has recently been completed and will report major adverse outcomes including major cardiovascular events in CKD patients [68].

There is extensive clinical trial evidence supporting the efficacy of IV iron preparations in patients with both non-dialysis-dependent and end-stage CKD [69-99] and patients with CHF [100-110], IBD [28,111-120], women's health (including abnormal uterine bleeding [121], peri and postpartum 
IDA [122-125], and prevention in pregnancy [126], and in various cancers [127-131], and in the perioperative management of anaemia [132]. Several observational cohort studies further support the efficacy and safety of IV iron in real-world clinical practice for IDA associated with CKD [133-142] (including dialysis patients hospitalised for infection [139]), IBD [143-145], pregnancy [146] and cancer $[147,148]$.

Multiple clinical guidelines relating to the management of iron deficiency in various healthcare fields including CKD, CHF, IBD, cancer and pregnancy note the benefit of IV iron as a treatment option for CKD for whom oral iron is not an option (lack of response, non-compliance, or intolerance) and for those patients with severe iron deficiency with the need for rapid iron replenishment $[149,150]$. As would be expected, the clinical evidence base underpinning these guidelines is strong. The 2018 European Society for Medical Oncology (ESMO) clinical practice guidelines for the management of anaemia and iron deficiency in patients with cancer reflect the most recent clinical data and strongly recommend IV iron in confirmed iron deficiency [151]. For chemotherapy-associated anaemia, IV iron makes an important contribution to improved response to erythropoiesis stimulating agents. In dialysis associated with CKD, IV iron is standard care practice [152].

\section{Evolving Evidence Base Identifies Differences between Third-Generation IV Irons}

Generally, reviews and meta-analyses provide valuable pooled results reporting the overall efficacy and safety profile of the class. Direct comparison between different irons are few, but with the increasing evidence pool and broadening of diseases assessed for IDA correction, some differences between irons are beginning to become apparent that may impact clinical practice.

In heart failure, iron deficiency is linked to disease severity and is only partly related to anaemia and is recognised as a marker of poor prognosis, independent of other prognostic factors [153-155]. IV iron improves patient well-being and New York Heart Association (NYHA) functional class, as reported in the FAIR-HF trial (Ferinject Assessment in Patients with Iron Deficiency and Chronic Heart Failure) in both anaemic and non-anaemic patients and exercise capacity over 24 weeks in the CONFIRM-HF trial (Ferric CarboxymaltOse evaluatioN on perFormance in patients with IRon deficiency in coMbination with chronic Heart Failure) $[107,156]$. In light of the evidence derived from trials of ferric carboxymaltose, the European Society of Cardiology guidelines for heart failure management makes a specific recommendation that ferric carboxymaltose should be considered in symptomatic patients to alleviate HF symptoms and improve exercise capacity and quality of life [150]. Whether other third generation irons have a similar impact is yet to be confirmed but is currently being investigated with results expected in 2021 (NCT02642562) [157].

Iron deficiency is highly prevalent in IBD, occurring in more than two-thirds of patients with Crohn's disease and ulcerative colitis [158,159]. Inflammatory bowel disease is perhaps a unique disease process with respect to IDA because of the multiple pathogenic mechanisms involved in its pathophysiology. Chronically inflamed intestinal mucosa with blood loss and micronutrient deficiency (iron and B12) are the primary mechanisms underlying the development of anaemia in IBD, with chronic inflammation, haemolysis, and medication-induced myelosuppression also thought to have roles [160]. A Bayesian network meta-analysis assessed the comparative efficacy and safety of different IV irons in patients with IBD and anaemia. This meta-analysis included five trials involving a relatively small number of patients $(n=1143)$ treated with IV iron (IS, ferric carboxymaltose, ferumoxytol, low-molecular-weight iron dextran, ferric gluconate, iron isomaltoside). Based on response rate, defined as $\mathrm{Hb}$ normalisation and/or increase by $\geq 2 \mathrm{~g} / \mathrm{dL}$, ferric carboxymaltose alone was shown to have superior efficacy than oral iron (OR $=1.9,95 \%$ CI: $1.1 ; 3.2)$ [161].

From a safety perspective, the two main side effects associated with IV iron are hypophosphataemia, apparent soon after infusion and lasting up to 2 weeks, and hypersensitivity reactions, as previously noted. The occurrence of hypophosphataemia has been investigated further. The underlying cause of the phenomenon is related to the expression of FGF-23, a hormone derived from osteocytes, with the ultimate consequence of renal phosphate excretion. A head-to-head 
retrospective analysis of 81 patients who received ferric carboxymaltose or iron isomaltoside identified hypophosphataemia almost exclusively in the ferric carboxymaltose-treated patients and caused by increased concentrations of FGF-23 [162]. A more recent study, the FIRM study in 1997 participants also demonstrated this difference in effect on phosphate when ferric carboxymaltose was compared with ferumoxytol [163]. This side effect highlights a subtle but potentially important different pharmacodynamic action of these two third generation IV irons. More data on hypophosphataemia is accruing; it is currently thought to be generally mild and usually without clinical consequence, but rare cases with clinical sequalae are apparent and this issue must be kept in consideration. The risk may be increased in patients with other disturbances of phosphate metabolism, such as hyperparathyroidism. A Danish retrospective analysis of 231 outpatients treated with IV iron infusions over a 2.5-year period, during which ferric carboxymaltose was switched to iron isomaltoside and back to ferric carboxymaltose in a stable cohort of patients largely with IBD [164], showed hypophosphataemia events were markedly more frequent in patients treated with ferric carboxymaltose than iron isomaltoside (64 vs. $9, p<0.01$ ). The study also reported that significantly more patients experienced hypersensitivity reactions with iron isomaltoside than ferric carboxymaltose $(2.5 \%$ vs. $10.7 \%, p<0.01)$, with no hypersensitivity crossover between the two drugs apparent. With the same amount of iron delivered with both drugs, this study suggests the differences in side effect profile relate to the different structures and properties of the two different IV iron drugs. More recent reviews have reassured that at least in patients with renal disease, the prevalence of serious adverse reactions is relatively low $[49,67,165,166]$.

\section{Conclusions}

IDA is a clinically important complication associated in particular with chronic inflammatory conditions, infection and other disease states and leads to chronic fatigue, reduced quality of life (QOL), increased risk of complications and increased mortality. Treatment of iron deficiency falls into two main categories, oral and IV iron formulations [167]. Clinical practice guidelines identify the benefits of IV iron preparations as a treatment option for patients with IDA who lack a response to, are non-compliant with, or are intolerant of oral iron treatment, as well as those who have severe iron deficiency and require rapid replenishment of available iron and $\mathrm{Hb}$ levels. IV iron has an important role in management of IDA perioperatively, particularly for emergency surgery, and there is now a robust clinical trial evidence base supporting the efficacy and safety of IV iron preparations in CKD, CHF, IBD, women's health and cancer.

The third generation of IV irons are characterised by unique carbohydrate ligands forming strongly bound iron-carbohydrate complexes. Their complexity is reflected in the guidance from regulators that generic formulations cannot be authorised by the generic approval process and goes against the view that IV irons are substitutable and interchangeable. The risk of infusion reactions is diminished compared with previous IV iron formulations, and these drugs are clinically well-tolerated at high doses to allow rapid, high-dose infusion that offers the potential for complete iron repletion in 15-60 min. As the evidence base and range of indications for which IV iron treatment is used expands, it is valuable to define the differences between these agents, in particular adverse event profiles, and reflect on how this might influence both the choice of iron and the decision to switch between IV irons in clinical practice.

Author Contributions: Conceptualization, S.B.; D.I.A.P. and H.D.; Writing-Original Draft Preparation, S.B.; Writing-Review \& Editing, S.B.; D.I.A.P.; H.F.C., and H.D; Visualization, H.F.C. Project Administration, S.B., and H.D.

Funding: This research received no external funding.

Acknowledgments: Search and editorial assistance was performed by Aidan McManus, PhD, of Edge Medical Communications, Dorking UK and was funded by Vifor Pharma Ltd.

Conflicts of Interest: D.I.A.P. is one of the inventors of an oral iron formulation for which she could receive future awards to inventors through the MRC Awards to Inventor scheme and has attended a Vifor-sponsored workshop. 
Notwithstanding, DIAP declares no conflict of interest with respect to this review manuscript. H.F.C. has no competing interest. S.B. has received honorarium for lectures from Vifor and Pharmacosmos in addition to funding to attend educational meetings. H.D. receives funding from Pfizer and La Jolla Pharmaceutical Company, and has attended a Vifor-sponsored Workshop, but declares no conflict of interest with respect to this review manuscript.

\section{References}

1. Paul, B.T.; Manz, D.H.; Torti, F.M.; Torti, S.V. Mitochondria and iron: Current questions. Expert Rev. Hematol. 2017, 10, 65-79. [CrossRef] [PubMed]

2. Anderson, C.P.; Shen, M.; Eisenstein, R.S.; Leibold, E.A. Mammalian iron metabolism and its control by iron regulatory proteins. Biochim. Biophys. Acta 2012, 1823, 1468-1483. [CrossRef] [PubMed]

3. Muckenthaler, M.U.; Rivella, S.; Hentze, M.W.; Galy, B. A red carpet for iron metabolism. Cell 2017, 168, 344-361. [CrossRef] [PubMed]

4. GBD 2016 Disease and Injury Incidence and Prevalence Collaborators. Global, regional, and national incidence, prevalence, and years lived with disability for 328 diseases and injuries for 195 countries, 1990-2016: A systematic analysis for the global burden of disease study 2016. Lancet 2017, 390, 1211-1259. [CrossRef]

5. Tolkien, Z.; Stecher, L.; Mander, A.P.; Pereira, D.I.; Powell, J.J. Ferrous sulfate supplementation causes significant gastrointestinal side-effects in adults: A systematic review and meta-analysis. PLoS ONE 2015, 10. [CrossRef] [PubMed]

6. Cappellini, M.D.; Comin-Colet, J.; de Francisco, A.; Dignass, A.; Doehner, W.; Lam, C.S.; Macdougall, I.C.; Rogler, G.; Camaschella, C.; Kadir, R.; et al. Iron deficiency across chronic inflammatory conditions: International expert opinion on definition, diagnosis, and management. Am. J. Hematol. 2017, 92, 1068-1078. [CrossRef] [PubMed]

7. Camaschella, C. Iron deficiency: New insights into diagnosis and treatment. Hematol. Am. Soc. Hematol. Educ. Program. 2015, 2015, 8-13. [CrossRef] [PubMed]

8. Butcher, A.; Richards, T. Cornerstones of patient blood management in surgery. Transfus. Med. 2017, 28, 150-157. [CrossRef] [PubMed]

9. Litton, E.; Xiao, J.; Ho, K.M. Safety and efficacy of intravenous iron therapy in reducing requirement for allogeneic blood transfusion: Systematic review and meta-analysis of randomised clinical trials. BMJ 2013, 347. [CrossRef] [PubMed]

10. Moretti, D.; Goede, J.S.; Zeder, C.; Jiskra, M.; Chatzinakou, V.; Tjalsma, H.; Melse-Boonstra, A.; Brittenham, G.; Swinkels, D.W.; Zimmermann, M.B. Oral iron supplements increase hepcidin and decrease iron absorption from daily or twice-daily doses in iron-depleted young women. Blood 2015, 126, 1981-1989. [CrossRef] [PubMed]

11. Stoffel, N.U.; Cercamondi, C.I.; Brittenham, G.; Zeder, C.; Geurts-Moespot, A.J.; Swinkels, D.W.; Moretti, D.; Zimmermann, M.B. Iron absorption from oral iron supplements given on consecutive versus alternate days and as single morning doses versus twice-daily split dosing in iron-depleted women: Two open-label, randomised controlled trials. Lancet Haematol. 2017, 4, e524-e533. [CrossRef]

12. Finberg, K.E.; Heeney, M.M.; Campagna, D.R.; Aydinok, Y.; Pearson, H.A.; Hartman, K.R.; Mayo, M.M.; Samuel, S.M.; Strouse, J.J.; Markianos, K.; et al. Mutations in tmprss6 cause iron-refractory iron deficiency anemia (irida). Nat. Genet. 2008, 40, 569-571. [CrossRef] [PubMed]

13. Girelli, D.; Ugolini, S.; Busti, F.; Marchi, G.; Castagna, A. Modern iron replacement therapy: Clinical and pathophysiological insights. Int. J. Hematol. 2018, 107, 16-30. [CrossRef] [PubMed]

14. Fishbane, S.; Block, G.A.; Loram, L.; Neylan, J.; Pergola, P.E.; Uhlig, K.; Chertow, G.M. Effects of ferric citrate in patients with nondialysis-dependent ckd and iron deficiency anemia. J. Am. Soc. Nephrol. 2017, 28, 1851-1858. [CrossRef] [PubMed]

15. Camaschella, C. Iron and hepcidin: A story of recycling and balance. Hematol. Am. Soc. Hematol. Educ. Program. 2013, 2013, 1-8. [CrossRef] [PubMed]

16. Schmidt, P.J. Regulation of iron metabolism by hepcidin under conditions of inflammation. J. Biol. Chem. 2015, 290, 18975-18983. [CrossRef] [PubMed]

17. Fishbane, S.; Spinowitz, B. Update on anemia in esrd and earlier stages of ckd: Core curriculum 2018. Am. J. Kidney Dis. 2018, 71, 423-435. [CrossRef] [PubMed] 
18. Fishbane, S. Balance of benefit and risk in intravenous iron treatment in chronic kidney disease. Semin. Nephrol. 2016, 36, 119-123. [CrossRef] [PubMed]

19. Weiss, G.; Goodnough, L.T. Anemia of chronic disease. N. Engl. J. Med. 2005, 352, 1011-1023. [CrossRef] [PubMed]

20. Auerbach, M.; Munoz, M.; Macdougall, I.C. Intravenous iron: Out of sight, out of mind. Lancet Haematol. 2018, 5, e10-e12. [CrossRef]

21. Hilty, F.M.; Arnold, M.; Hilbe, M.; Teleki, A.; Knijnenburg, J.T.; Ehrensperger, F.; Hurrell, R.F.; Pratsinis, S.E.; Langhans, W.; Zimmermann, M.B. Iron from nanocompounds containing iron and zinc is highly bioavailable in rats without tissue accumulation. Nat. Nanotechnol. 2010, 5, 374-380. [CrossRef] [PubMed]

22. Powell, J.J.; Bruggraber, S.F.; Faria, N.; Poots, L.K.; Hondow, N.; Pennycook, T.J.; Latunde-Dada, G.O.; Simpson, R.J.; Brown, A.P.; Pereira, D.I. A nano-disperse ferritin-core mimetic that efficiently corrects anemia without luminal iron redox activity. Nanomedicine 2014, 10, 1529-1538. [CrossRef] [PubMed]

23. Pisani, A.; Riccio, E.; Sabbatini, M.; Andreucci, M.; Del Rio, A.; Visciano, B. Effect of oral liposomal iron versus intravenous iron for treatment of iron deficiency anaemia in ckd patients: A. randomized trial. Nephrol. Dial. Transplant. 2015, 30, 645-652. [CrossRef] [PubMed]

24. Shafie, E.H.; Keshavarz, S.A.; Kefayati, M.E.; Taheri, F.; Sarbakhsh, P.; Vafa, M.R. The effects of nanoparticles containing iron on blood and inflammatory markers in comparison to ferrous sulfate in anemic rats. Int. J. Prev. Med. 2016, 7. [CrossRef]

25. Garces, V.; Rodriguez-Nogales, A.; Gonzalez, A.; Galvez, N.; Rodriguez-Cabezas, M.E.; Garcia-Martin, M.L.; Gutierrez, L.; Rondon, D.; Olivares, M.; Galvez, J.; et al. Bacteria-carried iron oxide nanoparticles for treatment of anemia. Bioconjug. Chem. 2018, 29, 1785-1791. [CrossRef] [PubMed]

26. Ganz, T. Systemic iron homeostasis. Physiol. Rev. 2013, 93, 1721-1741. [CrossRef] [PubMed]

27. Pereira, D.I.; Bruggraber, S.F.; Faria, N.; Poots, L.K.; Tagmount, M.A.; Aslam, M.F.; Frazer, D.M.; Vulpe, C.D.; Anderson, G.J.; Powell, J.J. Nanoparticulate iron(iii) oxo-hydroxide delivers safe iron that is well absorbed and utilised in humans. Nanomedicine 2014, 10, 1877-1886. [CrossRef] [PubMed]

28. Gasche, C.; Ahmad, T.; Tulassay, Z.; Baumgart, D.C.; Bokemeyer, B.; Buning, C.; Howaldt, S.; Stallmach, A.; Group, A.S. Ferric maltol is effective in correcting iron deficiency anemia in patients with inflammatory bowel disease: Results from a phase-3 clinical trial program. Inflamm. Bowel Dis. 2015, 21, 579-588. [CrossRef] [PubMed]

29. Barraclough, K.A.; Brown, F.; Hawley, C.M.; Leary, D.; Noble, E.; Campbell, S.B.; Isbel, N.M.; Mudge, D.W.; van Eps, C.L.; Johnson, D.W. A randomized controlled trial of oral heme iron polypeptide versus oral iron supplementation for the treatment of anaemia in peritoneal dialysis patients: Hematocrit trial. Nephrol. Dial. Transplant. 2012, 27, 4146-4153. [CrossRef] [PubMed]

30. Nagaraju, S.P.; Cohn, A.; Akbari, A.; Davis, J.L.; Zimmerman, D.L. Heme iron polypeptide for the treatment of iron deficiency anemia in non-dialysis chronic kidney disease patients: A randomized controlled trial. BMC Nephrol. 2013, 14. [CrossRef] [PubMed]

31. Auerbach, M.; Macdougall, I. The available intravenous iron formulations: History, efficacy, and toxicology. Hemodial. Int. 2017, 21 (Suppl. 1), S83-S92. [CrossRef] [PubMed]

32. Jahn, M.R.; Andreasen, H.B.; Futterer, S.; Nawroth, T.; Schunemann, V.; Kolb, U.; Hofmeister, W.; Munoz, M.; Bock, K.; Meldal, M.; et al. A comparative study of the physicochemical properties of iron isomaltoside 1000 (monofer), a new intravenous iron preparation and its clinical implications. Eur. J. Pharm. Biopharm. 2011, 78, 480-491. [CrossRef] [PubMed]

33. Grzywacz, A.; Lubas, A.; Fiedor, P.; Fiedor, M.; Niemczyk, S. Safety and efficacy of intravenous administration of iron preparations. Acta Pol. Pharm. 2017, 74, 13-24. [PubMed]

34. Neiser, S.; Koskenkorva, T.S.; Schwarz, K.; Wilhelm, M.; Burckhardt, S. Assessment of dextran antigenicity of intravenous iron preparations with enzyme-linked immunosorbent assay (elisa). Int. J. Mol. Sci. 2016, 17. [CrossRef] [PubMed]

35. Koskenkorva-Frank, T.S.; Weiss, G.; Koppenol, W.H.; Burckhardt, S. The complex interplay of iron metabolism, reactive oxygen species, and reactive nitrogen species: Insights into the potential of various iron therapies to induce oxidative and nitrosative stress. Free Radic. Biol. Med. 2013, 65, 1174-1194. [CrossRef] [PubMed]

36. Toblli, J.E.; Angerosa, M. Optimizing iron delivery in the management of anemia: Patient considerations and the role of ferric carboxymaltose. Drug Des. Dev. Ther. 2014, 8, 2475-2491. [CrossRef] [PubMed] 
37. Neiser, S.; Rentsch, D.; Dippon, U.; Kappler, A.; Weidler, P.G.; Gottlicher, J.; Steininger, R.; Wilhelm, M.; Braitsch, M.; Funk, F.; et al. Physico-chemical properties of the new generation iv iron preparations ferumoxytol, iron isomaltoside 1000 and ferric carboxymaltose. Biometals 2015, 28, 615-635. [CrossRef] [PubMed]

38. Pai, A.B. Complexity of intravenous iron nanoparticle formulations: Implications for bioequivalence evaluation. Ann. N. Y. Acad. Sci. 2017, 1407, 17-25. [CrossRef] [PubMed]

39. Geisser, P.; Burckhardt, S. The pharmacokinetics and pharmacodynamics of iron preparations. Pharmaceutics 2011, 3, 12-33. [CrossRef] [PubMed]

40. Chappell, H.F.; Thom, W.; Bowron, D.T.; Faria, N.; Hasnip, P.J.; Powell, J.J. Structure of naturally hydrated ferrihydrite revealed through neutron diffraction and first-principles modeling. Phys. Rev. Mater. 2017, 1. [CrossRef]

41. Gustafson, H.H.; Holt-Casper, D.; Grainger, D.W.; Ghandehari, H. Nanoparticle uptake: The phagocyte problem. Nano Today 2015, 10, 487-510. [CrossRef] [PubMed]

42. Skotland, T.; Sontum, P.C.; Oulie, I. In vitro stability analyses as a model for metabolism of ferromagnetic particles (clariscan), a contrast agent for magnetic resonance imaging. J. Pharm. Biomed. Anal. 2002, 28, 323-329. [CrossRef]

43. Maneeprakorn, W.; Maurizi, L.; Siriket, H.; Wutikhun, T.; Dharakul, T.; Hofmann, H. Superparamagnetic nanohybrids with cross-linked polymers providing higher in vitro stability. J. Mater. Sci. 2017, 52, 9249-9261. [CrossRef]

44. Corna, G.; Campana, L.; Pignatti, E.; Castiglioni, A.; Tagliafico, E.; Bosurgi, L.; Campanella, A.; Brunelli, S.; Manfredi, A.A.; Apostoli, P.; et al. Polarization dictates iron handling by inflammatory and alternatively activated macrophages. Haematologica 2010, 95, 1814-1822. [CrossRef] [PubMed]

45. Nairz, M.; Theurl, I.; Swirski, F.K.; Weiss, G. "Pumping iron"-how macrophages handle iron at the systemic, microenvironmental, and cellular levels. Pflugers Arch. 2017, 469, 397-418. [CrossRef] [PubMed]

46. Agoro, R.; Taleb, M.; Quesniaux, V.F.J.; Mura, C. Cell iron status influences macrophage polarization. PLoS ONE 2018, 13. [CrossRef] [PubMed]

47. Drakesmith, H.; Nemeth, E.; Ganz, T. Ironing out ferroportin. Cell Metab. 2015, 22, 777-787. [CrossRef] [PubMed]

48. Macdougall, I.C.; Vernon, K. Complement activation-related pseudo-allergy: A fresh look at hypersensitivity reactions to intravenous iron. Am. J. Nephrol. 2017, 45, 60-62. [CrossRef] [PubMed]

49. Munoz, M.; Gomez-Ramirez, S.; Bhandari, S. The safety of available treatment options for iron-deficiency anemia. Expert Opin. Drug Saf. 2018, 17, 149-159. [CrossRef] [PubMed]

50. Slotki, I.; Cabantchik, Z.I. The labile side of iron supplementation in ckd. J. Am. Soc. Nephrol. 2015, 26, 2612-2619. [CrossRef] [PubMed]

51. Cooke, M.; Lamplugh, A.; Naudeer, S.; Edey, M.; Bhandari, S. Efficacy and tolerability of accelerated-dose low-molecular-weight iron dextran (cosmofer) in patients with chronic kidney disease. Am. J. Nephrol. 2012, 35, 69-74. [CrossRef] [PubMed]

52. Sinha, S.; Chiu, D.; Peebles, G.; Swoboda, P.; Kolakkat, S.; Lamerton, E.; Fenwick, S.; Bhandari, S.; Kalra, P.A. Accelerated total dose infusion of low molecular weight iron dextran is safe and efficacious in chronic kidney disease patients. QJM 2011, 104, 221-230. [CrossRef] [PubMed]

53. Chertow, G.M.; Mason, P.D.; Vaage-Nilsen, O.; Ahlmen, J. Update on adverse drug events associated with parenteral iron. Nephrol. Dial. Transplant. 2006, 21, 378-382. [CrossRef] [PubMed]

54. Auerbach, M.; Pappadakis, J.A.; Bahrain, H.; Auerbach, S.A.; Ballard, H.; Dahl, N.V. Safety and efficacy of rapidly administered (one hour) one gram of low molecular weight iron dextran (infed) for the treatment of iron deficient anemia. Am. J. Hematol. 2011, 86, 860-862. [CrossRef] [PubMed]

55. Rampton, D.; Folkersen, J.; Fishbane, S.; Hedenus, M.; Howaldt, S.; Locatelli, F.; Patni, S.; Szebeni, J.; Weiss, G. Hypersensitivity reactions to intravenous iron: Guidance for risk minimization and management. Haematologica 2014, 99, 1671-1676. [CrossRef] [PubMed]

56. Di Francesco, T.; Philipp, E.; Borchard, G. Iron sucrose: Assessing the similarity between the originator drug and its intended copies. Ann. N. Y. Acad. Sci. 2017, 1407, 63-74. [CrossRef] [PubMed]

57. Toblli, J.E.; Cao, G.; Giani, J.F.; Dominici, F.P.; Angerosa, M. Nitrosative stress and apoptosis by intravenous ferumoxytol, iron isomaltoside 1000, iron dextran, iron sucrose, and ferric carboxymaltose in a nonclinical model. Drug Res. 2015, 65, 354-360. [CrossRef] [PubMed] 
58. Rottembourg, J.; Guerin, A.; Diaconita, M.; Kadri, A. The complete study of the switch from iron-sucrose originator to iron-sucrose similar and vice versa in hemodialysis patients. J. Kidney 2016, 2. [CrossRef]

59. Rottembourg, J.; Kadri, A.; Leonard, E.; Dansaert, A.; Lafuma, A. Do two intravenous iron sucrose preparations have the same efficacy? Nephrol. Dial. Transplant. 2011, 26, 3262-3267. [CrossRef] [PubMed]

60. Aguera, M.L.; Martin-Malo, A.; Alvarez-Lara, M.A.; Garcia-Montemayor, V.E.; Canton, P.; Soriano, S.; Aljama, P. Efficiency of original versus generic intravenous iron formulations in patients on haemodialysis. PLoS ONE 2015, 10. [CrossRef] [PubMed]

61. Stein, J.; Dignass, A.; Chow, K.U. Clinical case reports raise doubts about the therapeutic equivalence of an iron sucrose similar preparation compared with iron sucrose originator. Curr. Med. Res. Opin. 2012, 28, 241-243. [CrossRef] [PubMed]

62. Martin-Malo, A.; Merino, A.; Carracedo, J.; Alvarez-Lara, M.A.; Ojeda, R.; Soriano, S.; Crespo, R.; Ramirez, R.; Aljama, P. Effects of intravenous iron on mononuclear cells during the haemodialysis session. Nephrol. Dial. Transplant. 2012, 27, 2465-2471. [CrossRef] [PubMed]

63. Lee, E.S.; Park, B.R.; Kim, J.S.; Choi, G.Y.; Lee, J.J.; Lee, I.S. Comparison of adverse event profile of intravenous iron sucrose and iron sucrose similar in postpartum and gynecologic operative patients. Curr. Med. Res. Opin. 2013, 29, 141-147. [CrossRef] [PubMed]

64. FDA. Draft Guidance on Iron Sucrose. Available online: https://www.fda.gov/downloads/Drugs/ GuidanceComplianceRegulatoryInformation/Guidances/UCM297630.pdf (accessed on 15 March 2018).

65. FDA. Draft Guidance on Sodium Ferric Gluconate Complex. Available online: https://www.fda.gov/ downloads/drugs/guidancecomplianceregulatoryinformation/guidances/ucm358142.pdf (accessed on 15 March 2018).

66. EMA. Reflection Paper on the Data Requirements for Intravenous Iron-Based Nano-Colloidal Products Developed with Reference to an Innovator Medicinal Product. Ema/chmp/swp/620008/2012. Available online: http:/ / www.ema.europa.eu/docs/en_GB/document_library/Scientific_guideline/2015/ 03/WC500184922 (accessed on 23 February 2018).

67. Avni, T.; Bieber, A.; Grossman, A.; Green, H.; Leibovici, L.; Gafter-Gvili, A. The safety of intravenous iron preparations: Systematic review and meta-analysis. Mayo Clin. Proc. 2015, 90, 12-23. [CrossRef] [PubMed]

68. EU Clinical Trials Register. UK Multicentre Open-Label Randomised Controlled Trial of Iv Iron Therapy in Incident Haemodialysis Patients. 2013-002267-25. Available online: https:/ / www.clinicaltrialsregister.eu/ ctr-search/search (accessed on 07 June 2018).

69. Macdougall, I.C.; Bock, A.H.; Carrera, F.; Eckardt, K.U.; Gaillard, C.; Van Wyck, D.; Meier, Y.; Larroque, S.; Roger, S.D.; FIND-CKD Study investigators. Renal function in patients with non-dialysis chronic kidney disease receiving intravenous ferric carboxymaltose: An analysis of the randomized find-ckd trial. BMC Nephrol. 2017, 18. [CrossRef] [PubMed]

70. Gaillard, C.A.; Bock, A.H.; Carrera, F.; Eckardt, K.U.; Van Wyck, D.B.; Bansal, S.S.; Cronin, M.; Meier, Y.; Larroque, S.; Roger, S.D.; et al. Hepcidin response to iron therapy in patients with non-dialysis dependent ckd: An analysis of the find-ckd trial. PLoS ONE 2016, 11. [CrossRef] [PubMed]

71. Kalra, P.A.; Bhandari, S.; Saxena, S.; Agarwal, D.; Wirtz, G.; Kletzmayr, J.; Thomsen, L.L.; Coyne, D.W. A randomized trial of iron isomaltoside 1000 versus oral iron in non-dialysis-dependent chronic kidney disease patients with anaemia. Nephrol. Dial. Transplant. 2016, 31, 646-655. [CrossRef] [PubMed]

72. Syed, A.; Bhandari, S. Correction of iron deficiency anaemia using iv cosmofer in ckd patients with asthma: A prospective study. QJM 2016, 109, 187-190. [CrossRef] [PubMed]

73. Toblli, J.E.; Di Gennaro, F. Switching patients with non-dialysis chronic kidney disease from oral iron to intravenous ferric carboxymaltose: Effects on erythropoiesis-stimulating agent requirements, costs, hemoglobin and iron status. PLoS ONE 2015, 10. [CrossRef] [PubMed]

74. Macdougall, I.C.; Bock, A.H.; Carrera, F.; Eckardt, K.U.; Gaillard, C.; Van Wyck, D.; Roubert, B.; Nolen, J.G.; Roger, S.D.; Investigators, F.-C.S. Find-ckd: A randomized trial of intravenous ferric carboxymaltose versus oral iron in patients with chronic kidney disease and iron deficiency anaemia. Nephrol. Dial. Transplant. 2014, 29, 2075-2084. [CrossRef] [PubMed]

75. Bhandari, S.; Kalra, P.A.; Kothari, J.; Ambuhl, P.M.; Christensen, J.H.; Essaian, A.M.; Thomsen, L.L.; Macdougall, I.C.; Coyne, D.W. A randomized, open-label trial of iron isomaltoside 1000 (monofer(r)) compared with iron sucrose (venofer(r)) as maintenance therapy in haemodialysis patients. Nephrol. Dial. Transplant. 2015, 30, 1577-1589. [CrossRef] [PubMed] 
76. Kuji, T.; Toya, Y.; Fujikawa, T.; Kakimoto-Shino, M.; Nishihara, M.; Shibata, K.; Tamura, K.; Hirawa, N.; Satta, H.; Kawata, S.; et al. Acceleration of iron utilization after intravenous iron administration during activated erythropoiesis in hemodialysis patients: A randomized study. Ther. Apher. Dial. 2015, 19, 131-137. [CrossRef] [PubMed]

77. Macdougall, I.C.; Strauss, W.E.; McLaughlin, J.; Li, Z.; Dellanna, F.; Hertel, J. A randomized comparison of ferumoxytol and iron sucrose for treating iron deficiency anemia in patients with ckd. Clin. J. Am. Soc. Nephrol. 2014, 9, 705-712. [CrossRef] [PubMed]

78. Onken, J.E.; Bregman, D.B.; Harrington, R.A.; Morris, D.; Buerkert, J.; Hamerski, D.; Iftikhar, H.; Mangoo-Karim, R.; Martin, E.R.; Martinez, C.O.; et al. Ferric carboxymaltose in patients with iron-deficiency anemia and impaired renal function: The repair-ida trial. Nephrol. Dial. Transplant. 2014, 29, 833-842. [CrossRef] [PubMed]

79. Arogundade, F.A.; Soyinka, F.O.; Sanusi, A.A.; Ojo, O.E.; Akinsola, A. Iron status and benefit of the use of parenteral iron therapy in pre-dialysis chronic kidney disease patients. Niger. Postgrad. Med. J. 2013, 20, 299-304. [PubMed]

80. Charytan, C.; Bernardo, M.V.; Koch, T.A.; Butcher, A.; Morris, D.; Bregman, D.B. Intravenous ferric carboxymaltose versus standard medical care in the treatment of iron deficiency anemia in patients with chronic kidney disease: A randomized, active-controlled, multi-center study. Nephrol. Dial. Transplant. 2013, 28, 953-964. [CrossRef] [PubMed]

81. Wikstrom, B.; Bhandari, S.; Barany, P.; Kalra, P.A.; Ladefoged, S.; Wilske, J.; Thomsen, L.L. Iron isomaltoside 1000: A new intravenous iron for treating iron deficiency in chronic kidney disease. J. Nephrol. 2011, 24, 589-596. [CrossRef] [PubMed]

82. Adhikary, L.; Acharya, S. Efficacy of iv iron compared to oral iron for increment of haemoglobin level in anemic chronic kidney disease patients on erythropoietin therapy. J. Nepal Med. Assoc. 2011, 51, 133-136.

83. Qunibi, W.Y.; Martinez, C.; Smith, M.; Benjamin, J.; Mangione, A.; Roger, S.D. A randomized controlled trial comparing intravenous ferric carboxymaltose with oral iron for treatment of iron deficiency anaemia of non-dialysis-dependent chronic kidney disease patients. Nephrol. Dial. Transplant. 2011, 26, 1599-1607. [CrossRef] [PubMed]

84. Covic, A.; Mircescu, G. The safety and efficacy of intravenous ferric carboxymaltose in anaemic patients undergoing haemodialysis: A multi-centre, open-label, clinical study. Nephrol. Dial. Transplant. 2010, 25, 2722-2730. [CrossRef] [PubMed]

85. Bailie, G.R.; Mason, N.A.; Valaoras, T.G. Safety and tolerability of intravenous ferric carboxymaltose in patients with iron deficiency anemia. Hemodial. Int. 2010, 14, 47-54. [CrossRef] [PubMed]

86. Spinowitz, B.S.; Kausz, A.T.; Baptista, J.; Noble, S.D.; Sothinathan, R.; Bernardo, M.V.; Brenner, L.; Pereira, B.J. Ferumoxytol for treating iron deficiency anemia in ckd. J. Am. Soc. Nephrol. 2008, 19, 1599-1605. [CrossRef] [PubMed]

87. Agarwal, R.; Rizkala, A.R.; Bastani, B.; Kaskas, M.O.; Leehey, D.J.; Besarab, A. A randomized controlled trial of oral versus intravenous iron in chronic kidney disease. Am. J. Nephrol. 2006, 26, 445-454. [CrossRef] [PubMed]

88. Mircescu, G.; Garneata, L.; Capusa, C.; Ursea, N. Intravenous iron supplementation for the treatment of anaemia in pre-dialyzed chronic renal failure patients. Nephrol. Dial. Transplant. 2006, 21, 120-124. [CrossRef] [PubMed]

89. Van Wyck, D.B.; Roppolo, M.; Martinez, C.O.; Mazey, R.M.; McMurray, S.; United States Iron Sucrose Clinical Trials, G. A randomized, controlled trial comparing iv iron sucrose to oral iron in anemic patients with nondialysis-dependent ckd. Kidney Int. 2005, 68, 2846-2856. [CrossRef] [PubMed]

90. Charytan, C.; Qunibi, W.; Bailie, G.R.; Venofer Clinical Studies, G. Comparison of intravenous iron sucrose to oral iron in the treatment of anemic patients with chronic kidney disease not on dialysis. Nephron Clin. Pract. 2005, 100, C55-C62. [CrossRef] [PubMed]

91. Goldstein, S.L.; Morris, D.; Warady, B.A. Comparison of the safety and efficacy of 3 iron sucrose iron maintenance regimens in children, adolescents, and young adults with ckd: A randomized controlled trial. Am. J. Kidney Dis. 2013, 61, 588-597. [CrossRef] [PubMed]

92. Li, X.; Kshirsagar, A.V.; Brookhart, M.A. Safety of intravenous iron in hemodialysis patients. Hemodial. Int. 2017, 21 (Suppl. 1), S93-S103. [CrossRef] [PubMed] 
93. Aronoff, G.R.; Bennett, W.M.; Blumenthal, S.; Charytan, C.; Pennell, J.P.; Reed, J.; Rothstein, M.; Strom, J.; Wolfe, A.; Van Wyck, D.; et al. Iron sucrose in hemodialysis patients: Safety of replacement and maintenance regimens. Kidney Int. 2004, 66, 1193-1198. [CrossRef] [PubMed]

94. Chandler, G.; Harchowal, J.; Macdougall, I.C. Intravenous iron sucrose: Establishing a safe dose. Am. J. Kidney Dis. 2001, 38, 988-991. [CrossRef] [PubMed]

95. Charytan, C.; Levin, N.; Al-Saloum, M.; Hafeez, T.; Gagnon, S.; Van Wyck, D.B. Efficacy and safety of iron sucrose for iron deficiency in patients with dialysis-associated anemia: North American clinical trial. Am. J. Kidney Dis. 2001, 37, 300-307. [CrossRef] [PubMed]

96. Van Wyck, D.B.; Cavallo, G.; Spinowitz, B.S.; Adhikarla, R.; Gagnon, S.; Charytan, C.; Levin, N. Safety and efficacy of iron sucrose in patients sensitive to iron dextran: North American clinical trial. Am. J. Kidney Dis. 2000, 36, 88-97. [CrossRef] [PubMed]

97. Roger, S.D.; Gaillard, C.A.; Bock, A.H.; Carrera, F.; Eckardt, K.U.; Van Wyck, D.B.; Cronin, M.; Meier, Y.; Larroque, S.; Macdougall, I.C.; et al. Safety of intravenous ferric carboxymaltose versus oral iron in patients with nondialysis-dependent ckd: An analysis of the 1-year find-ckd trial. Nephrol. Dial. Transplant. 2017, 32, 1530-1539. [CrossRef] [PubMed]

98. Macdougall, I.C.; Bock, A.H.; Carrera, F.; Eckardt, K.U.; Gaillard, C.; Wyck, D.V.; Meier, Y.; Larroque, S.; Perrin, A.; Roger, S.D. Erythropoietic response to oral iron in patients with nondialysis-dependent chronic kidney disease in the find-ckd trial. Clin. Nephrol. 2017, 88, 301-310. [CrossRef] [PubMed]

99. Zeidan, A.; Bhandari, S. Anemia in peritoneal dialysis patients; iron repletion, current and future therapies. Perit. Dial. Int. 2017, 37, 6-13. [CrossRef] [PubMed]

100. Van Veldhuisen, D.J.; Ponikowski, P.; van der Meer, P.; Metra, M.; Bohm, M.; Doletsky, A.; Voors, A.A.; Macdougall, I.C.; Anker, S.D.; Roubert, B.; et al. Effect of ferric carboxymaltose on exercise capacity in patients with chronic heart failure and iron deficiency. Circulation 2017, 136, 1374-1383. [CrossRef] [PubMed]

101. Toblli, J.E.; Di Gennaro, F.; Rivas, C. Changes in echocardiographic parameters in iron deficiency patients with heart failure and chronic kidney disease treated with intravenous iron. Heart Lung Circ. 2015, 24, 686-695. [CrossRef] [PubMed]

102. Ponikowski, P.; van Veldhuisen, D.J.; Comin-Colet, J.; Ertl, G.; Komajda, M.; Mareev, V.; McDonagh, T.; Parkhomenko, A.; Tavazzi, L.; Levesque, V.; et al. Beneficial effects of long-term intravenous iron therapy with ferric carboxymaltose in patients with symptomatic heart failure and iron deficiencydagger. Eur. Heart J. 2015, 36, 657-668. [CrossRef] [PubMed]

103. Filippatos, G.; Farmakis, D.; Colet, J.C.; Dickstein, K.; Luscher, T.F.; Willenheimer, R.; Parissis, J.; Gaudesius, G.; Mori, C.; von Eisenhart Rothe, B.; et al. Intravenous ferric carboxymaltose in iron-deficient chronic heart failure patients with and without anaemia: A subanalysis of the fair-hf trial. Eur. J. Heart Fail. 2013, 15, 1267-1276. [CrossRef] [PubMed]

104. Beck-da-Silva, L.; Piardi, D.; Soder, S.; Rohde, L.E.; Pereira-Barretto, A.C.; de Albuquerque, D.; Bocchi, E.; Vilas-Boas, F.; Moura, L.Z.; Montera, M.W.; et al. Iron-hf study: A randomized trial to assess the effects of iron in heart failure patients with anemia. Int. J. Cardiol. 2013, 168, 3439-3442. [CrossRef] [PubMed]

105. Van Craenenbroeck, E.M.; Conraads, V.M.; Greenlaw, N.; Gaudesius, G.; Mori, C.; Ponikowski, P.; Anker, S.D. The effect of intravenous ferric carboxymaltose on red cell distribution width: A subanalysis of the fair-hf study. Eur. J. Heart Fail. 2013, 15, 756-762. [CrossRef] [PubMed]

106. Comin-Colet, J.; Lainscak, M.; Dickstein, K.; Filippatos, G.S.; Johnson, P.; Luscher, T.F.; Mori, C.; Willenheimer, R.; Ponikowski, P.; Anker, S.D. The effect of intravenous ferric carboxymaltose on health-related quality of life in patients with chronic heart failure and iron deficiency: A subanalysis of the fair-hf study. Eur. Heart J. 2013, 34, 30-38. [CrossRef] [PubMed]

107. Anker, S.D.; Comin Colet, J.; Filippatos, G.; Willenheimer, R.; Dickstein, K.; Drexler, H.; Luscher, T.F.; Bart, B.; Banasiak, W.; Niegowska, J.; et al. Ferric carboxymaltose in patients with heart failure and iron deficiency. N. Engl. J. Med. 2009, 361, 2436-2448. [CrossRef] [PubMed]

108. Okonko, D.O.; Grzeslo, A.; Witkowski, T.; Mandal, A.K.; Slater, R.M.; Roughton, M.; Foldes, G.; Thum, T.; Majda, J.; Banasiak, W.; et al. Effect of intravenous iron sucrose on exercise tolerance in anemic and nonanemic patients with symptomatic chronic heart failure and iron deficiency ferric-hf: A randomized, controlled, observer-blinded trial. J. Am. Coll. Cardiol. 2008, 51, 103-112. [CrossRef] [PubMed] 
109. Bolger, A.P.; Bartlett, F.R.; Penston, H.S.; O'Leary, J.; Pollock, N.; Kaprielian, R.; Chapman, C.M. Intravenous iron alone for the treatment of anemia in patients with chronic heart failure. J. Am. Coll. Cardiol. 2006, 48, 1225-1227. [CrossRef] [PubMed]

110. Minana, G.; Cardells, I.; Palau, P.; Llacer, P.; Facila, L.; Almenar, L.; Lopez-Lereu, M.P.; Monmeneu, J.V.; Amiguet, M.; Gonzalez, J.; et al. Changes in myocardial iron content following administration of intravenous iron (myocardial-iron): Study design. Clin. Cardiol. 2018, 41, 729-735. [CrossRef] [PubMed]

111. Dahlerup, J.F.; Jacobsen, B.A.; van der Woude, J.; Bark, L.A.; Thomsen, L.L.; Lindgren, S. High-dose fast infusion of parenteral iron isomaltoside is efficacious in inflammatory bowel disease patients with iron-deficiency anaemia without profound changes in phosphate or fibroblast growth factor 23. Scand. J. Gastroenterol. 2016, 51, 1332-1338. [CrossRef] [PubMed]

112. Reinisch, W.; Altorjay, I.; Zsigmond, F.; Primas, C.; Vogelsang, H.; Novacek, G.; Reinisch, S.; Thomsen, L.L. A 1-year trial of repeated high-dose intravenous iron isomaltoside 1000 to maintain stable hemoglobin levels in inflammatory bowel disease. Scand. J. Gastroenterol. 2015, 50, 1226-1233. [CrossRef] [PubMed]

113. Reinisch, W.; Staun, M.; Tandon, R.K.; Altorjay, I.; Thillainayagam, A.V.; Gratzer, C.; Nijhawan, S.; Thomsen, L.L. A randomized, open-label, non-inferiority study of intravenous iron isomaltoside 1,000 (monofer) compared with oral iron for treatment of anemia in ibd (proceed). Am. J. Gastroenterol. 2013, 108, 1877-1888. [CrossRef] [PubMed]

114. Nordfjeld, K.; Andreasen, H.; Thomsen, L.L. Pharmacokinetics of iron isomaltoside 1000 in patients with inflammatory bowel disease. Drug Des. Dev. Ther. 2012, 6, 43-51. [CrossRef] [PubMed]

115. Evstatiev, R.; Marteau, P.; Iqbal, T.; Khalif, I.L.; Stein, J.; Bokemeyer, B.; Chopey, I.V.; Gutzwiller, F.S.; Riopel, L.; Gasche, C.; et al. Fergicor, a randomized controlled trial on ferric carboxymaltose for iron deficiency anemia in inflammatory bowel disease. Gastroenterology 2011, 141, 846-853. [CrossRef] [PubMed]

116. Koutroubakis, I.E.; Oustamanolakis, P.; Karakoidas, C.; Mantzaris, G.J.; Kouroumalis, E.A. Safety and efficacy of total-dose infusion of low molecular weight iron dextran for iron deficiency anemia in patients with inflammatory bowel disease. Digest. Dis. Sci. 2010, 55, 2327-2331. [CrossRef] [PubMed]

117. Lindgren, S.; Wikman, O.; Befrits, R.; Blom, H.; Eriksson, A.; Granno, C.; Ung, K.A.; Hjortswang, H.; Lindgren, A.; Unge, P. Intravenous iron sucrose is superior to oral iron sulphate for correcting anaemia and restoring iron stores in ibd patients: A randomized, controlled, evaluator-blind, multicentre study. Scand. J. Gastroenterol. 2009, 44, 838-845. [CrossRef] [PubMed]

118. Kulnigg, S.; Stoinov, S.; Simanenkov, V.; Dudar, L.V.; Karnafel, W.; Garcia, L.C.; Sambuelli, A.M.; D’Haens, G.; Gasche, C. A novel intravenous iron formulation for treatment of anemia in inflammatory bowel disease: The ferric carboxymaltose (ferinject) randomized controlled trial. Am. J. Gastroenterol. 2008, 103, 1182-1192. [CrossRef] [PubMed]

119. Schroder, O.; Mickisch, O.; Seidler, U.; de Weerth, A.; Dignass, A.U.; Herfarth, H.; Reinshagen, M.; Schreiber, S.; Junge, U.; Schrott, M.; et al. Intravenous iron sucrose versus oral iron supplementation for the treatment of iron deficiency anemia in patients with inflammatory bowel disease-A randomized, controlled, open-label, multicenter study. Am. J. Gastroenterol. 2005, 100, 2503-2509. [CrossRef] [PubMed]

120. Erichsen, K.; Ulvik, R.J.; Nysaeter, G.; Johansen, J.; Ostborg, J.; Berstad, A.; Berge, R.K.; Hausken, T. Oral ferrous fumarate or intravenous iron sucrose for patients with inflammatory bowel disease. Scand. J. Gastroenterol. 2005, 40, 1058-1065. [CrossRef] [PubMed]

121. Mahey, R.; Kriplani, A.; Mogili, K.D.; Bhatla, N.; Kachhawa, G.; Saxena, R. Randomized controlled trial comparing ferric carboxymaltose and iron sucrose for treatment of iron deficiency anemia due to abnormal uterine bleeding. Int. J. Gynaecol. Obstet. 2016, 133, 43-48. [CrossRef] [PubMed]

122. Tariq, N.; Ayub, R.; Khan, W.U.; Ijaz, S.; Alam, A.Y. Parenteral iron therapy in the treatment of iron deficiency anemia during pregnancy: A randomized controlled trial. J. Coll. Physicians Surg. Pak. 2015, 25, 193-197. [PubMed]

123. Kochhar, P.K.; Kaundal, A.; Ghosh, P. Intravenous iron sucrose versus oral iron in treatment of iron deficiency anemia in pregnancy: A randomized clinical trial. J. Obstet. Gynaecol. Res. 2013, 39, 504-510. [CrossRef] [PubMed]

124. Ayub, R.; Tariq, N.; Adil, M.M.; Iqbal, M.; Junaid, A.; Jaferry, T. Efficacy and safety of total dose infusion of low molecular weight iron dextran in the treatment of iron deficiency anemia during pregnancy. J. Coll. Physicians Surg. Pak. 2008, 18, 424-427. [PubMed] 
125. Al, R.A.; Unlubilgin, E.; Kandemir, O.; Yalvac, S.; Cakir, L.; Haberal, A. Intravenous versus oral iron for treatment of anemia in pregnancy: A randomized trial. Obstet. Gynecol. 2005, 106, 1335-1340. [CrossRef] [PubMed]

126. Bencaiova, G.; von Mandach, U.; Zimmermann, R. Iron prophylaxis in pregnancy: Intravenous route versus oral route. Eur. J. Obstet. Gynecol. Reprod. Biol. 2009, 144, 135-139. [CrossRef] [PubMed]

127. Keeler, B.D.; Simpson, J.A.; Ng, O.; Padmanabhan, H.; Brookes, M.J.; Acheson, A.G.; Group, I.T. Randomized clinical trial of preoperative oral versus intravenous iron in anaemic patients with colorectal cancer. Br. J. Surg. 2017, 104, 214-221. [CrossRef] [PubMed]

128. Birgegard, G.; Henry, D.; Glaspy, J.; Chopra, R.; Thomsen, L.L.; Auerbach, M. A randomized noninferiority trial of intravenous iron isomaltoside versus oral iron sulfate in patients with nonmyeloid malignancies and anemia receiving chemotherapy: The profound trial. Pharmacotherapy 2016, 36, 402-414. [CrossRef] [PubMed]

129. Borstlap, W.A.A.; Buskens, C.J.; Tytgat, K.; Tuynman, J.B.; Consten, E.C.J.; Tolboom, R.C.; Heuff, G.; van Geloven, N.; van Wagensveld, B.A.; Wientjes, C.A.C.A.; et al. Multicentre randomized controlled trial comparing ferric(iii)carboxymaltose infusion with oral iron supplementation in the treatment of preoperative anaemia in colorectal cancer patients. BMC Surg. 2015, 15. [CrossRef]

130. Hedenus, M.; Karlsson, T.; Ludwig, H.; Rzychon, B.; Felder, M.; Roubert, B.; Birgegard, G. Intravenous iron alone resolves anemia in patients with functional iron deficiency and lymphoid malignancies undergoing chemotherapy. Med. Oncol. 2014, 31. [CrossRef] [PubMed]

131. Dangsuwan, P.; Manchana, T. Blood transfusion reduction with intravenous iron in gynecologic cancer patients receiving chemotherapy. Gynecol. Oncol. 2010, 116, 522-525. [CrossRef] [PubMed]

132. Froessler, B.; Cocchiaro, C.; Saadat-Gilani, K.; Hodyl, N.; Dekker, G. Intravenous iron sucrose versus oral iron ferrous sulfate for antenatal and postpartum iron deficiency anemia: A randomized trial. J. Matern. Fetal. Neonatal Med. 2013, 26, 654-659. [CrossRef] [PubMed]

133. Michels, W.M.; Jaar, B.G.; Ephraim, P.L.; Liu, Y.; Miskulin, D.C.; Tangri, N.; Crews, D.C.; Scialla, J.J.; Shafi, T.; Sozio, S.M.; et al. Intravenous iron administration strategies and anemia management in hemodialysis patients. Nephrol. Dial. Transplant. 2017, 32, 173-181. [CrossRef] [PubMed]

134. Brookhart, M.A.; Freburger, J.K.; Ellis, A.R.; Winkelmayer, W.C.; Wang, L.; Kshirsagar, A.V. Comparative short-term safety of sodium ferric gluconate versus iron sucrose in hemodialysis patients. Am. J. Kidney Dis. 2016, 67, 119-127. [CrossRef] [PubMed]

135. Airy, M.; Mandayam, S.; Mitani, A.A.; Chang, T.I.; Ding, V.Y.; Brookhart, M.A.; Goldstein, B.A.; Winkelmayer, W.C. Comparative outcomes of predominant facility-level use of ferumoxytol versus other intravenous iron formulations in incident hemodialysis patients. Nephrol. Dial. Transplant. 2015, 30, 2068-2075. [CrossRef] [PubMed]

136. Hazara, A.M.; Bhandari, S. Intravenous iron administration is associated with reduced platelet counts in patients with chronic kidney disease. J. Clin. Pharm. Ther. 2015, 40, 20-23. [CrossRef] [PubMed]

137. Zitt, E.; Sturm, G.; Kronenberg, F.; Neyer, U.; Knoll, F.; Lhotta, K.; Weiss, G. Iron supplementation and mortality in incident dialysis patients: An observational study. PLoS ONE 2014, 9. [CrossRef] [PubMed]

138. Schiller, B.; Bhat, P.; Sharma, A. Safety and effectiveness of ferumoxytol in hemodialysis patients at 3 dialysis chains in the united states over a 12-month period. Clin. Ther. 2014, 36, 70-83. [CrossRef] [PubMed]

139. Ishida, J.H.; Marafino, B.J.; McCulloch, C.E.; Dalrymple, L.S.; Dudley, R.A.; Grimes, B.A.; Johansen, K.L. Receipt of intravenous iron and clinical outcomes among hemodialysis patients hospitalized for infection. Clin. J. Am. Soc. Nephrol. 2015, 10, 1799-1805. [CrossRef] [PubMed]

140. Tangri, N.; Miskulin, D.C.; Zhou, J.; Bandeen-Roche, K.; Michels, W.M.; Ephraim, P.L.; McDermott, A.; Crews, D.C.; Scialla, J.J.; Sozio, S.M.; et al. Effect of intravenous iron use on hospitalizations in patients undergoing hemodialysis: A comparative effectiveness analysis from the decide-esrd study. Nephrol. Dial. Transplant. 2015, 30, 667-675. [CrossRef] [PubMed]

141. Miskulin, D.C.; Tangri, N.; Bandeen-Roche, K.; Zhou, J.; McDermott, A.; Meyer, K.B.; Ephraim, P.L.; Michels, W.M.; Jaar, B.G.; Crews, D.C.; et al. Intravenous iron exposure and mortality in patients on hemodialysis. Clin. J. Am. Soc. Nephrol. 2014, 9, 1930-1939. [CrossRef] [PubMed]

142. Kshirsagar, A.V.; Freburger, J.K.; Ellis, A.R.; Wang, L.; Winkelmayer, W.C.; Brookhart, M.A. Intravenous iron supplementation practices and short-term risk of cardiovascular events in hemodialysis patients. PLoS ONE 2013, 8. [CrossRef] [PubMed] 
143. Garcia-Lopez, S.; Bocos, J.M.; Gisbert, J.P.; Bajador, E.; Chaparro, M.; Castano, C.; Garcia-Erce, J.A.; Gomollon, F. High-dose intravenous treatment in iron deficiency anaemia in inflammatory bowel disease: Early efficacy and impact on quality of life. Blood Transfus. 2016, 14, 199-205. [CrossRef] [PubMed]

144. Cortes, X.; Borras-Blasco, J.; Moles, J.R.; Bosca, M.; Cortes, E. Safety of ferric carboxymaltose immediately after infliximab administration, in a single session, in inflammatory bowel disease patients with iron deficiency: A pilot study. PLoS ONE 2015, 10. [CrossRef] [PubMed]

145. Befrits, R.; Wikman, O.; Blomquist, L.; Hjortswang, H.; Hammarlund, P.; Bajor, A.; Klintman, D.; Blom, H. Anemia and iron deficiency in inflammatory bowel disease: An open, prospective, observational study on diagnosis, treatment with ferric carboxymaltose and quality of life. Scand. J. Gastroenterol. 2013, 48, 1027-1032. [CrossRef] [PubMed]

146. Froessler, B.; Collingwood, J.; Hodyl, N.A.; Dekker, G. Intravenous ferric carboxymaltose for anaemia in pregnancy. BMC Preg. Childbirth 2014, 14. [CrossRef] [PubMed]

147. Calleja, J.L.; Delgado, S.; del Val, A.; Hervas, A.; Larraona, J.L.; Teran, A.; Cucala, M.; Mearin, F.; Colon Cancer Study Group. Ferric carboxymaltose reduces transfusions and hospital stay in patients with colon cancer and anemia. Int. J. Colorectal Dis. 2016, 31, 543-551. [CrossRef] [PubMed]

148. Toledano, A.; Luporsi, E.; Morere, J.F.; Scotte, F.; Laribi, K.; Barriere, J.; Huot-Marchand, P.; Duvillie, L.; Concas, V.H.; Bugat, R. Clinical use of ferric carboxymaltose in patients with solid tumours or haematological malignancies in France. Support. Care Cancer 2016, 24, 67-75. [CrossRef] [PubMed]

149. KDIGO. Kidney disease: Improving global outcomes (kdigo) anemia work group. Kdigo clinical practice guideline for anemia in chronic kidney disease. Kidney Int. Suppl. 2012, 2, 279-335.

150. Ponikowski, P.; Voors, A.A.; Anker, S.D.; Bueno, H.; Cleland, J.G.; Coats, A.J.; Falk, V.; Gonzalez-Juanatey, J.R.; Harjola, V.P.; Jankowska, E.A.; et al. 2016 esc guidelines for the diagnosis and treatment of acute and chronic heart failure: The task force for the diagnosis and treatment of acute and chronic heart failure of the european society of cardiology (esc). Developed with the special contribution of the heart failure association (hfa) of the esc. Eur. J. Heart Fail. 2016, 18, 891-975. [CrossRef] [PubMed]

151. Aapro, M.; Beguin, Y.; Bokemeyer, C.; Dicato, M.; Gascon, P.; Glaspy, J.; Hofmann, A.; Link, H.; Littlewood, T.; Ludwig, H.; et al. Management of anaemia and iron deficiency in patients with cancer: Esmo clinical practice guidelines. Ann. Oncol. 2018. [CrossRef]

152. Mikhail, A.; Brown, C.; Williams, J.A.; Mathrani, V.; Shrivastava, R.; Evans, J.; Isaac, H.; Bhandari, S. Renal association clinical practice guideline on anaemia of chronic kidney disease. BMC Nephrol. 2017, 18. [CrossRef] [PubMed]

153. Jankowska, E.A.; Rozentryt, P.; Witkowska, A.; Nowak, J.; Hartmann, O.; Ponikowska, B.; Borodulin-Nadzieja, L.; Banasiak, W.; Polonski, L.; Filippatos, G.; et al. Iron deficiency: An ominous sign in patients with systolic chronic heart failure. Eur. Heart J. 2010, 31, 1872-1880. [CrossRef] [PubMed]

154. Klip, I.T.; Comin-Colet, J.; Voors, A.A.; Ponikowski, P.; Enjuanes, C.; Banasiak, W.; Lok, D.J.; Rosentryt, P.; Torrens, A.; Polonski, L.; et al. Iron deficiency in chronic heart failure: An international pooled analysis. Am. Heart J. 2013, 165, 575-582. [CrossRef] [PubMed]

155. Klip, I.T.; Jankowska, E.A.; Enjuanes, C.; Voors, A.A.; Banasiak, W.; Bruguera, J.; Rozentryt, P.; Polonski, L.; van Veldhuisen, D.J.; Ponikowski, P.; et al. The additive burden of iron deficiency in the cardiorenal-anaemia axis: Scope of a problem and its consequences. Eur. J. Heart Fail. 2014, 16, 655-662. [CrossRef] [PubMed]

156. Ponikowski, P.; Filippatos, G.; Colet, J.C.; Willenheimer, R.; Dickstein, K.; Luscher, T.; Gaudesius, G.; von Eisenhart Rothe, B.; Mori, C.; Greenlaw, N.; et al. The impact of intravenous ferric carboxymaltose on renal function: An analysis of the fair-hf study. Eur. J. Heart Fail. 2015, 17, 329-339. [CrossRef] [PubMed]

157. Clinicaltrials.Gov. Intravenous Iron Treatment in Patients with Heart Failure and Iron Deficiency: Ironman. NCT02642562. Available online: https:/ / clinicaltrials.gov/ct2/show / NCT02642562 (accessed on 07 June 2018).

158. Alves, R.A.; Miszputen, S.J.; Figueiredo, M.S. Anemia in inflammatory bowel disease: Prevalence, differential diagnosis and association with clinical and laboratory variables. Sao Paulo Med. J. 2014, 132, 140-146. [CrossRef] [PubMed]

159. Filmann, N.; Rey, J.; Schneeweiss, S.; Ardizzone, S.; Bager, P.; Bergamaschi, G.; Koutroubakis, I.; Lindgren, S.; Morena Fde, L.; Moum, B.; et al. Prevalence of anemia in inflammatory bowel diseases in european countries: A systematic review and individual patient data meta-analysis. Inflamm. Bowel Dis. 2014, 20, 936-945. [CrossRef] [PubMed] 
160. Kaitha, S.; Bashir, M.; Ali, T. Iron deficiency anemia in inflammatory bowel disease. World J. Gastrointest. Pathophysiol. 2015, 6, 62-72. [CrossRef] [PubMed]

161. Aksan, A.; Isik, H.; Radeke, H.H.; Dignass, A.; Stein, J. Systematic review with network meta-analysis: Comparative efficacy and tolerability of different intravenous iron formulations for the treatment of iron deficiency anaemia in patients with inflammatory bowel disease. Aliment. Pharmacol. Ther. 2017, 45, 1303-1318. [CrossRef] [PubMed]

162. Schaefer, B.; Wurtinger, P.; Finkenstedt, A.; Braithwaite, V.; Viveiros, A.; Effenberger, M.; Sulzbacher, I.; Moschen, A.; Griesmacher, A.; Tilg, H.; et al. Choice of high-dose intravenous iron preparation determines hypophosphatemia risk. PLoS ONE 2016, 11. [CrossRef] [PubMed]

163. Adkinson, N.F.; Strauss, W.E.; Macdougall, I.C.; Bernard, K.E.; Auerbach, M.; Kaper, R.F.; Chertow, G.M.; Krop, J.S. Comparative safety of intravenous ferumoxytol versus ferric carboxymaltose in iron deficiency anemia: A randomized trial. Am. J. Hematol. 2018, 93, 683-690. [CrossRef] [PubMed]

164. Bager, P.; Hvas, C.L.; Dahlerup, J.F. Drug-specific hypophosphatemia and hypersensitivity reactions following different intravenous iron infusions. Br. J. Clin. Pharmacol. 2017, 83, 1118-1125. [CrossRef] [PubMed]

165. Wang, C.; Graham, D.J.; Kane, R.C.; Xie, D.; Wernecke, M.; Levenson, M.; MaCurdy, T.E.; Houstoun, M.; Ryan, Q.; Wong, S.; et al. Comparative risk of anaphylactic reactions associated with intravenous iron products. JAMA 2015, 314, 2062-2068. [CrossRef] [PubMed]

166. Kalra, P.A.; Bhandari, S. Safety of intravenous iron use in chronic kidney disease. Curr. Opin. Nephrol. Hypertens. 2016, 25, 529-535. [CrossRef] [PubMed]

167. Camaschella, C. Iron-deficiency anemia. N. Engl. J. Med. 2015, 372, 1832-1843. [CrossRef] [PubMed]

(C) 2018 by the authors. Licensee MDPI, Basel, Switzerland. This article is an open access article distributed under the terms and conditions of the Creative Commons Attribution (CC BY) license (http:/ / creativecommons.org/licenses/by/4.0/). 